\title{
Correction to: Drama-Based Activities for STEM Education: Encouraging Scientific Aspirations and Debunking Stereotypes in Secondary School Students in Spain and the UK
}

\author{
Sergio Villanueva Baselga ${ }^{1,2}$ (D) Oriol Marimon Garrido ${ }^{3} \cdot$ Helena González Burón $^{3}$ \\ Published online: 27 October 2020 \\ (C) Springer Nature B.V. 2020
}

\section{Correction to: Research in Science Education \\ https://doi.org/10.1007/s11165-020-09939-5}

The original version of this article unfortunately contained a mistake. The author would like to add the below text as acknowledgement:

"Authors would like to thank Maria Heras at Autonomous University of Barcelona, Isabel Ruiz Mallen at Open University of Catalonia, and Eric Jensen at University of Warwick for their kind contributions and helpful guidance in the design of the items of the questionnaires."

Publisher's Note Springer Nature remains neutral with regard to jurisdictional claims in published maps and institutional affiliations.

The online version of the original article can be found at https://doi.org/10.1007/s11165-020-09939-5

Sergio Villanueva Baselga

sergio.villanueva@ub.edu

Oriol Marimon Garrido

marimon.oriol@gmail.com

Helena González Burón

helena.gobu@gmail.com

1 Department of Library and Information Science and Audiovisual Communication, Universitat de Barcelona, Carrer Melcior de Palau, 140, 08014 Barcelona, Spain

2 Centre for Research in Information, Communication and Culture (CRICC), Universitat de Barcelona, Carrer Melcior de Palau, 140, 08014 Barcelona, Spain

3 Big Van Ciencia, Avinguda Sant Ferran, 25, 08940 Cornella de Llobregat, Spain 